\title{
PENERAPAN MULTIMEDIA INTERAKTIF BERBASIS SMARTPHONE UNTUK MENINGKATKAN PEMAHAMAN KONSEP MAHASISWA PADA MATA KULIAH FISIKA DASAR
}

\author{
Ali Ismail \\ STKIP Garut \\ *E-mail: ai7garut@gmail.com
}

\begin{abstract}
Abstrak
Tujuan yang ingin dicapai dari penelitian ini adalah untuk menganalisis peningkatan pemahaman konsep mahasiswa sebagai hasil dari pembelajaran multimedia interaktif berbasis smartphone dibandingkan dengan yang mendapatkan pembelajaran secara konvensional. Penelitian ini menggunakan metode penelitian kuasi eksperimen dengan desain penelitian randomized control group Pretest-Potstest design. populasi dari penelitian ini adalah seluruh mahasiswa jurusan farmasi di universitas garut sedangkan sampel dari penelitian ini adalah di pilih dua dari keseluruhan populasi satu kelas sebagai kelas ekperiment dengan menggunakan multimedia interaktif berbasis smartphone satu kelas lagi sebagai kelas Kontrol dengan menggunakan model pembelajaran konvensional. Hasil penelitian menunjukan bahwa dilihat dari nilai gainnya pemahaman konsep mahasiswa setelah diterapkan multimedia interaktif berbasis smartphone meningkat lebih signifikan di bandingkan dengan peningkatan pemahaman konsep siswa yang menggunakan model pembelajaran konvensional. Berdasarkan hasil analisis data diperoleh rata-rata $\mathrm{N}$-gain pemahaman konsep 0,67 untuk kelas eksperimen dan 0.46 untuk kelas kontrol, sedangkan berdasarkan uji statistic pre test perhitungan uji-t menunjukan bahwa tidak terdapat perbedaan yang signifikan antara pemahaman mahasiswa kelas eksperimen dan kelas kontrol. Hal itu berarti keadaan awal mahasiswa kelas eksperimen dan kontrol mempunyai kemampua pemahaman awal yang sama. Sedangkan pengujian data post test menunjukan bahwa hasil dari perhitungan uji-t, $t_{\text {hitung }}>t_{t a b e l}$ dapat disimpulkan bahwa terdapat perbedaan kemampuan akhir pada kelas eksperimen dan kelas kontrol. Dapat disimpulkan bahwa terdapat perbedaan yang signifikan antara kelas yang menggunakan multimedia interaktif berbasis smartphone dibandingkan kelas yang menggunakan model konvensional dalam proses pembelajarannya Dapat disimpulkan bahwa multimedia interaktif berbasis smartphone dapat lebih meningkatkan pemahaman konsep mahasiswa di bandingkan dengan pembelajaran konvensional
\end{abstract}

Kata kunci: Multimedia interaktif, smartphone, pemahaman konsep 
PENDAHULUAN

Pembelajaran adalah"proses interaksi peserta didik dengan pendidik dan sumber belajar pada suatu lingkungan belajar". Sumber belajar adalah segala bentuk yang dapat memberikan informasi belajar untuk mahasiswa, contohnya perpustakaan, laboratorium, audio visual, dll. Sedangkan lingkungan belajar mencakup tujuan pembelajaran, peserta didik, dosen, kurikulum, strategi pembelajaran, media pembelajaran, dan penilaian pembelajaran. Unsur-unsur tersebut dikenal sebagai komponen-komponen pembelajaran.

Proses pembelajaran ditandai oleh adanya interaksi antara komponenkomponen pembelajaran, misalnya komponen mahasiswa berinteraksi dengan komponen dosen, media, dan lingkungan kelas; komponen dosen berinteraksi dengan komponen-komponen mahasiswa, metode, media, peralatan, dan unsur tenaga kependidikan lainnya yang terarah pada pencapaian tujuan pembelajaran.

Hakikatnya proses pembelajaran adalah proses komunikasi, yaitu proses penyampaian pesan dari sumber pesan ke penerima pesan. Pesan yang dikomunikasikan adalah materi ajar yang ada dalam kurikulum, sumber pesannya guru, media pembelajaran; penerima pesannya adalah mahasiswa.

Pesan berupa isi ajaran yang ada dalam kurikulum dituangkan oleh dosen kedalam simbol-simbol komunikasi baik verbal (kata-kata \& tulisan) maupun non-verbal, proses ini dinamakan encoding. Penafsiran simbol-simbol komunikasi tersebut oleh mahasiswa dinamakan decoding.

Pada saat ini kita juga sedang memasuki era informasi. Teknologi dan komunikasi (TIK) yang terus berkembang dan cenderung akan terus mempengaruhi segenap kehidupan manusia. Perkembangan di bidang teknologi informasi dan komunikasi yang sangat cepat ini berpengaruh juga terhadap pribadi, aktivitas, kehidupan ataupun cara berpikir. Perkembangan ini perlu juga dikenalkan pada mahasiswa agar mereka mempunyai bekal pengetahuan dan pengalaman untuk menerapkan dan menggunakan TIK dalam kegiatan belajar mengajar. Dalam pembelajaran terdiri dari beberapa aspek di antaranya desai,pengembangan, pemanfatan, implementasi dan evaluasi (Nasurlloh \& Ismail, 2017)

Dalam proses pembelajaran saat ini banyak dikembangkan media-media pembelajaran berbasis komputer, salah satunya pembuatan dan pengembangan software dalam media pembelajaran. Perkembangan TIK ini memungkinkan dihasilkannnya berbagai multimedia dalam pembelajaran yang dapat memudahkan dan membangkitkan motivasi belajar mahasiswa dalam mempelajari konsep Fisika. Menurut beberapa penelitian diantaranya yang di ungkapkan ismail (2017) mengungkapkan bahwa, pembelajaran berbasis multimedia interaktif dapat meningkatkan prestasi belajar siswa. Sedangkan hasil penelitian Selahattin (2006) menunjukkan bahwa komputer dan kontruktivis sama-sama dapat meningkatkan pemahaman konsep elekstrostatik, namun siswa yang belajar dengan komputer lebih baik pada tingkat pengetahuan dan pengertian, dibandingkan model kontruktivis. Hasil penelitian di atas memungkinkan untuk diterapkan pada materi fisika yang lain dengan menggunakan media pembelajaran produk TIK.

Pada pembelajaran fisika kehadiran media pembelajaran sudah menjadi suatu keharusan. Salah satu alasannya karena pada fisika banyak konsep-konsep yang bersifat abstrak. Contohnya pada pokok bahasan teori Kinetik Gas, pada pokok bahasan ini mahasiswa mempelajari sifatsifat dari gas ideal (bersifat abstrak) yang 
dalam penyampaiannya memerlukan visualisasi agar mudah untuk dimengerti mahasiswa.

Kurangnya penggunaan media dalam proses pembelajaran fisika, dapat mengakibatkan komunikasi guru dalam menyampaikan materi ajar ke siswa berlangsung secara tidak efektif dan efisien. Sehingga memungkinkan terjadinya perbedaan pemahaman konsep fisika antar guru, siswa, kesulitan siswa dalam memahami fisika, rendahnya keterampilan berpikir kreatif siswa dan lain-lain. Jika dibiarkan dapat mengakibatkan rendahnya kualitas proses belajar siswa yang berakibat pada rendahnya hasil belajar siswa pada mata pelajaran fisika.

Kemajuan teknologi digital yang sangat pesat harus dapat dimanfaatkan secara maksimal khususnya digunakan untuk menunjang proses pembelajaran baik didalam kelas maupun kegiatan lapangan. Kemajuan teknologi seluler seperti tablet, smartphone dan gadget yang semakin berkembang dengan fitur-fitur yang canggih dan semakin lengkap seharusnya dapat dimanfaatkan secara maksimal dalam pembelajaran. Pembelajaran abad 21 mengharuskan adanya integrasi teknologi dalam proses pembelajaran. Smartphone dan perangkat digital lainnya dapat dijadikan sumber yang cukup potensial dalam menunjang pembelajaran. Perangkat mobile seperti laptop, smartphone, digital assistant memiliki potensi besar dalam menunjang pembelajaran di dalam dan di luar kelas (Sung, et al., 2015). Hal ini tentu saja jika aplikasi smartphone diimplementasikan dalam pembelajaran lebih menguntungkan dari pada pembelajaran secara tradisional, secara tidak langsung akan meningkatkan keterlibatan siswa dalam pembelajaran. Aplikasi smartphone dapat membantu siswa dengan cepat untuk memahami konsep baru secara jelas dan meningkatkan kepercayaan diri yang tinggi dibandingkan dengan daripada siswa yang mendapatkan pembelaran secara tradisional, menggabungkan aplikasi smartphone dalam pembelajaran memiliki potensi positif yang dapat mempengaruhi belajar siswa (Shih, et al., 2016). Sejumlah aplikasi smartphone dapat menyelaraskan kerjasama antar kelompok dalam pembelajaran, menambah pengalaman dan membantu siswa dalam meningkatkan pembelajaran kolaboratif (France, et al., 2016).

Upaya dalam mengembangkan berbagai metode atau model inovatif dalam pembelajaran terus dilakukan salah satunya menggunakan teknologi smartphone. Kemajuan teknologi smartphone mempengaruhi hampir semua elemen masyarakat, termasuk dikalangan akademik. Namun, kemajuan aplikasi smartphone sangat kurang diintegrasikan dalam proses pembelajaran. Jelas dalam hal ini beberapa aplikasi smartphone dapat dikembangkan dalam upaya membuat sebuah inovasi dalam pembelajaran. banyak keuntungan yang akan didapatkan dalam proses pembelajaran. Belajar dengan menggunakan aplikasi smartphone tidak terbatas oleh ruang dan tidak fokus didalam kelas, hal ini akan memberikan keleluasaan bagi siswa untuk mengeksplorasi pengetahuannya lebih luas, jika dikembangkan secara khusus dapat membantu meningkatkan praktik belajar dan memberikan peluang lebih lanjut untuk membangun koneksi, membina kerjasama antara mahasiswa dan dosen (Gikas \& Grant, 2013; Vázquez-Cano, 2014). Di era yang serba canggih ini sudah selayaknya aplikasi smartphone dapat di implementasikan secara maksimal, tentu saja harus dikembangkan terlebih dahulu sesuai dengan konteksnya. Aplikasi smartphone dapat dikembangkan dan disesuaikan dengan platform untuk 
meningkatkan pembelajaran sehinggga proses pembelajaran akan lebih cepat dan efektif (Li, et al., 2016).

Selain memberikan pengalaman baru dengan mengintegrasikan aplikasi smartphone, siswa/mahasiswa juga akan lebih tertarik untuk mengikuti pembelajaran sehingga dapat meningkatkan keterlibatan mereka dalam pembelajaran. Selain itu, aplikasi mobile dapat dikembangkan dengan aplikasi mobile $3 D$ untuk meningkatkan hasil belajar yang lebih baik daripada metode standard dan dapat diintegrasikan dalam kurikulum (Noguera, et al. 2013).

Implementasi teknologi smartphone dapat meningkatkan mobilitas belajar siswa. Mobilitas belajar yang rendah akan memberikan dampak yang negatif dalam pencapaian hasil belajar. Penurunan mobilitas belajar banyak dipicu oleh berbagai hal, salah satunya pembelajaran yang monoton yang hanya menggunakan metode konvesional. Belajar dengan menggunakan perangkat smartphone akan meningkatkan mobilitas mahasiswa dan mengaktifkan pembelajaran otentik dengan bantuan beberapa fitur seperti media sosial, video, mikroblog, foto dan perangkat lainnya yang dapat mendukung dalam proses pembelajaran (Gikas \& Grant, 2013) membantu mahasiwa untuk melek digital (Thomas \& Fellowes, 2016) dan dapat digunakan untuk belajar jarak jauh (Vázquez-Cano, 2014). Pembelajaran menggunakan aplikasi smartphone cukup praktis dibandingkan dengan menggunakan komputer atau laptop. Dalam perspektif pembelajaran abad 21, perangkat yang lebih mudah digunakan dan kompatibel dengan tugas-tugas belajar akan berdampak positif terhadap motivasi siswa untuk menggunakan (Hopkins, et al., 2016). Menggunakan perangkat mobile dalam pembelajaran lebih baik daripada menggunakan komputer, smartphone dapat diterapkan untuk berbagai usia, berbagai metode, berbagai instruksi dan berbagai domain mata pelajaran sehingga dapat meningkatkan pengetahuan siswa secara luas (Ahmed \& Parsons, 2013; Sung, et al., 2015) membangun keselarasan kerjasama antar kelompok (France, et al., 2016) proses pembelajaran akan lebih cepat dan efektif (Li, et al., 2016).

Berdasarkan uraian di atas, maka dipandang perlu dilakukan suatu penelitian mengenai "Penerapan multimedia interaktif berbasis smartphone untuk meningkatkan pemahaman konsep mahasiswa pada mata kuliah fisika dasar".

Berdasarkan latar belakang masalah yang telah diuraikan diatas, maka permasalahan dalam penelitian ini dapat dirumuskan dalam bentuk pertanyaan sebagai berikut: "apakah multimedia interaktif berbasis smartphone dapat lebih meningkatkan pemahaman konsep mahasiswa di banding model pembelajaran konvensional?".

Untuk lebih mengarahkan penelitian, maka rumusan masalah di atas dijabarkan menjadi beberapa pertanyaan penelitian sebagai berikut:

1) Bagimanakah peningkatan pemahaman konsep mahasiswa yang mendapatkan pembelajaran dengan multimedia interaktif berbasis smartphone?

2) Bagimanakah peningkatan pemahaman konsep mahasiswa yang mendapatkan pembelajaran konvensional?

3) Bagaimanakah perbandingan peningkatan pemahaman konsep mahasiswa antara yang mendapatkan multimedia interaktif berbasis smartphone dengan yang mendapatkan pembelajaran secara konvensional? 
Berdasarkan rumusan masalah diatas, tujuan yang ingin dicapai dari penelitian ini adalah untuk menganalisis peningkatan pemahaman konsep mahasiswa sebagai hasil dari pembelajaran multimedia interaktif berbasis smartphone dibandingkan dengan yang mendapatkan pembelajaran secara konvensional,

\section{Multimedia}

\section{TINJAUAN PUSTAKA}

Pengertian multimedia secara bahasa berasal dari bahasa latin yakni multi yang berarti banyak, bermacam-macam, dan medium yang berarti media adalah suatu alat untuk menyampaikan atau membawa sesuatu baik itu informasi atau yang lainnya. Multimedia dapat diartikan sebagai alat atau media yang menggabungkan dua unsur atau lebih yang terdiri dari teks, grafis, gambar, foto, suara, audio, video dan animasi secara terintegrasi (kusnandar dkk, 2007).

Menurut Wahono (seperti dikutip Warsita, 2008, h.155) multimedia dibedakan menjadi dua yaitu:

1. Multimedia Linier

Multimedia linier adalah suatu multimedia yang tidak dilengkapi dengan alat pengontrol apapun yang dapat dioperasikan oleh pengguna, contohnya adalah TV dan Film, sehingga penggunanya hanya menjadi penonton dan menikmati multimedia yang disajikan dari awal hingga akhir.

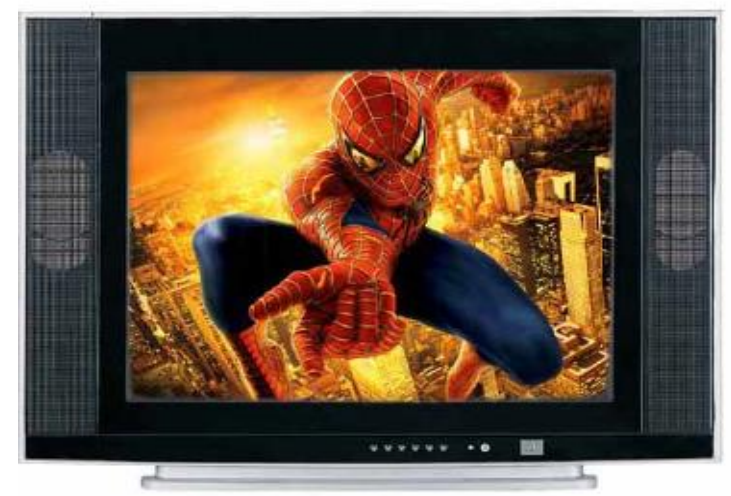

Gambar. 1 Multimedia linier
2. Multimedia Interaktif

Multimedia interaktif adalah suatu multimedia yang dilengkapi denga alat pengontrol yang dapat dioperasikan oleh pengguna, sehingga pengguna dapat memilih apa yang dikehendaki untuk proses selanjutnya. Melalui prose situ ada timbal balik antara pengguna dengan multimedia. Contoh multimedia interaktif diantaranya adalah: multimedia pembelajaran interaktif, aplikasi game, dan lain-lain (Kusnandar dkk, 2007). Sedangkan menurut Hofstetter (seperti dikutip Periangan, 2011) Multimedia interaktif adalah pemanfaatan komputer untuk membuat dan menggabungkan teks, grafik, audio, gambar bergerak (video dan animasi) dengan menggabungkan link dan tool yang memungkinkan pemakai melakukan navigasi, berintraksi, berkreasi dan berkomunikasi.

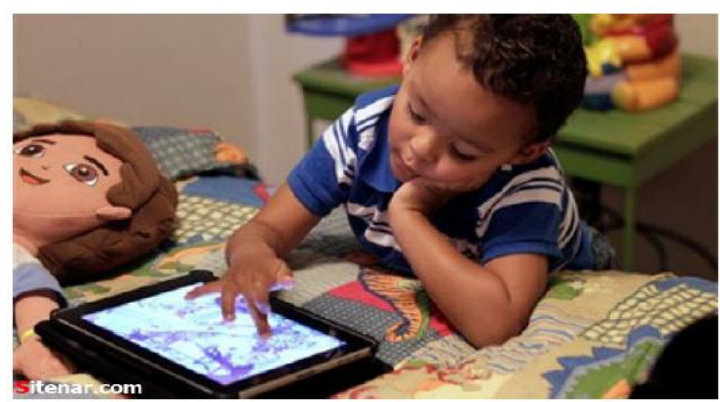

Gambar. 2 Multimedia interakrif

\section{Smartphone}

Smartphone (telepon cerdas) adalah pengembangan dari telepon genggam, smartphone mempunyai kemampuan melebihi dari telepon genggam pada umumnya baik dari kelebihan perangkat keras dan perangkat lunak yang dimiliki oleh smartphone. Menurut Brusco (seperti dikutip Yanti, 2011, h. 3) smartphone adalah mobile phone yang memiliki fungsi seperti sistem komputerisasi, pengiriman pesan (email), akses internet dan memiliki berbagai aplikasi sebagai sarana pencarian informasi seperti kesehatan, olahraga, uang dan berbagai macam topik. 
Dalam hal fitur, berbagai macam smartphone yang telah beredar di Indonesia mempunyai fitur seperti miniatur papan ketik QWERTY, layar sentuh, kamera, sistem navigasi, pemutar musik, penjelajah internet, penjelajah foto, melihat klip video, kemampuan membaca dokumen dan lainlain. Pada umumnya smartphone menggunakan berbagai macam sistem operasi yang berbeda. Sistem operasi yang dapat ditemukan di smartphone yang saat ini telah beredar di Indonesia diantaranya adalah Symbian Os, iPhone OS, RIM Blackberry, Windows Mobile, dan Android.

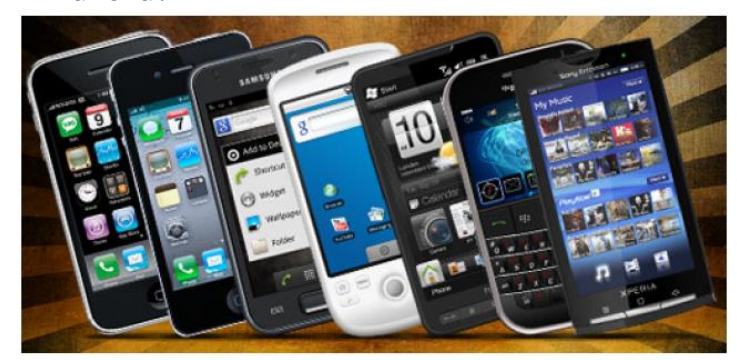

Gambar. 2 Macam-macam smartphone

\section{Android}

Android adalah salah satu perangkat lunak sistem operasi yang berbasis Linux dan dirancang terutama untuk smartphone dan komputer tablet dengan layar sentuh. Berbeda dengan perangkat lunak sistem operasi lainnya, Android bersifat terbuka terhadap pengembang yang ingin menciptakan aplikasi mereka sendiri. Faktor ini yang menjadikan Android sebagai perangkat lunak sistem operasi mobile yang terpopuler didunia seperti yang dilansir pada situs resmi Android www.android.com (anonim, 2013, para.1 ). Android.inc didirikan di Palo Alto, California pada bulan oktober tahun 2003 oleh Andy Rubin, Rich Miner, Nick sears dan Chris White yang kemudian diakuisisi oleh google pada tahun 2005. Sejak awal kemunculannya pada tahun 2008 sampai kini, Android telah meluncurkan beberapa versi. Dari Android versi 1.1 pada tahun 2009 sampai yang terbaru adalah Android versi nougat pada tahun 2017.

\section{Pemahaman Konsep}

Anderson Et Al. Menyatakan understand is defined as constructing the meaning of instructional messages, including oral, written, and graphic communication. Pendapat tersebut menjelaskan bahwa seseorang dikatakan memahami sesuatu jika mereka mampu mengkonstruksi makna dari pesan-pesan pengajaran seperti komunikasi lisan, tulisan, dan grafik. Seseorang mampu memahami suatu pengetahuan baru ketika mampu membangun hubungan antara pengetahuan yang baru diintegrasikan tersebut dengan skema kognitif yang sudah ada padanya. Tingkat pemahaman seseorang terhadap suatu konsep dapat dilihat dari jenis-jenis pemahaman yang dimilikinya.

Kategori memahami mencakup tujuh proses kognitif : menafsirkan (interpreting), memberikan contoh (exemplifying), mengkelasifikasikan (classifying), meringkas (summarizing), menarik inferensi (inferring), membandingkan (comparing), dan menjelaskan (explaining)

\section{METODE/EKSPERIMEN}

Penelitian ini menggunakan metode kuasi eksperimen (eksperimen semu). Metode eksperimen semu digunakan untuk mengetahui perbandingan peningkatan pemahaman konsep mahasiswa antara mahasiswa yang mendapatkan pembelajaran dengan multimedia interaktif berbasis smartphone dengan yang mendapatkan pembelajaran dengan pembelajaran konvensional.

Desain eksperimen yang digunakan adalah "The randomized Pretest-Posttest control group design" (Fraenkel dan Wallen, 2007). Eksperimen dilakukan dengan memberikan perlakuan pembelajaran dengan multimedia interaktif 
berbasis smartphone pada kelompok eksperimen dan pembelajaran konvensional pada kelompok kontrol. Secara bagan, desain penelitian yang digunakan dapat digambarkan dalam Tabel 1 di bawah ini:

Tabel 1 Randomized Control Group Pretest Postest Design

\begin{tabular}{|l|c|c|c|}
\hline \multicolumn{1}{|c|}{ Kelompok } & Pretes & Perlakuan & Postes \\
\hline \hline E (Eksperimen) & $\mathrm{Y}$ & $\mathrm{X}_{\mathrm{a}}$ & $\mathrm{Y}$ \\
$\mathrm{K}$ (Kontrol) & $\mathrm{Y}$ & - & $\mathrm{Y}$ \\
\hline
\end{tabular}

Penelitian ini terdiri dari dua variabel, yaitu variabel bebas dan variabel terikat. Variabel bebas adalah variabel yang mempengaruhi atau yang menjadi sebab perubahannya atau timbulnya variable terikat. Sedangkan variabel terikat merupakan variabel yang dipengaruhi atau yang menjadi akibat, karena adanya variabel bebas. Variabel yang diukur dalam penelitian ini adalah pemahaman konsep mahasiswa dengan menggunakan multimedia interaktif berbasis smarthphone.

Subyek penelitian ini adalah mahasiswa farmasi di universitas garut yang berada di kabupaten Garut Provinsi Jawa Barat pada tahun pelajaran 2016/2017. Teknik pengambilan sampel adalah dengan cara purposive sampling. Sebagai sampel penelitian dipilih dua kelas secara acak dari lima kelas yang memiliki kemampuan yang setara tanpa mengacak mahasiswa tiap kelasnya. Pengelompokkan sampel terdiri dari satu kelas eksperimen dan satu kelas kontrol..

Instrumen yang digunakan adalah instrument pretest, postest, Sebelum instrumen tes ini digunakan dalam kelas penelitian, instrumen tes ini diujicobakan terlebih dahulu untuk mengetahui tingkat validitas, reliabilitas, daya pembeda dan tingkat kesukaran masing-masing butir soal. Hal tersebut dilakukan untuk mengetahui kualitas dari setiap butir soal yang digunakan untuk mengukur kemampuan ranah kognitif mahasiswa. Sehingga dari hasil uji instrument tersebut dapat diketahui apakah instrument tes tersebut layak digunakan dalam penelitian atau tidak.

Data dari hasil pretes dan post test dianalisis dengan langkah-langkah:

1) Pemberian Skor

2) Perhitungan Gain skor

3) Pengujian Terhadap Hipotesis

Pada umumnya pengujian terhadap hipotesis dapat dilakukan dengan uji parametrik dan non-parametrik. Uji parametrik dapat dilakukan jika asumsiasumsi penelitian parametrik dipenuhi, antara lain jika data dalam pengujian hipotesis ini, data yang dimaksud ialah peningkatan (gain) skor yang dicapai kedua kelas bersifat normal dan memiliki varians yang homogen. Jika asumsi-asumsi penelitian parametrik tersebut tidak terpenuhi, maka pengujian terhadap hipotesis harus dilakukan dengan uji nonparametrik. Oleh karena itu, untuk mengetahui pengujian statistik mana yang tepat, sebelumnya perlu diketahui normalitas dan homogenitas dari gain kedua kelas.

1. Uji Nomalitas

Uji normalitas dalam penelitian ini menggunakan Uji Kolmogorov-smirnov dengan taraf signifikansi $(\alpha)=0,05$. Apabila nilai sig $>\alpha$ maka $\mathrm{H}_{\mathrm{i}}$ diterima, atau $\mathrm{H}_{\mathrm{o}}$ ditolak dengan kata lain bahwa data tersebut berdistribusi normal, dengan $\alpha=0,05$.

2. Uji Homogenitas Varians

Pengujian ini dilakukan untuk melihat apakah data-data nilai yang didapat dari kedua kelompok ini memiliki kesamaan varians atau tidak. Apabila nilai dari sig $>\alpha$ 
maka $\mathrm{H}_{\mathrm{i}}$ diterima, atau $\mathrm{H}_{\mathrm{o}}$ ditolak dengan kata lain bahwa varians untuk kedua data tersebut adalah homogen.

Uji statistik parametrik akan dilakukan jika gain kedua kelompok terdistribusi normal dan memiliki varians yang homogen. Untuk menguji hipotesis dengan menggunakan uji-t dengan sampel kecil $(\mathrm{n}<30)$ pada tingkat signifikansi 0,05 dengan tes satu ekor, rumus yang digunakan ialah :

$$
t=\frac{M_{1}-M_{2}}{\sqrt{\frac{\left(N_{1}-1\right) S_{1}^{2}+\left(N_{2}-1\right) S_{2}^{2}}{N_{1}+N_{2}-2}\left(\frac{1}{N_{1}}+\frac{1}{N_{2}}\right)}}
$$

(Luhut Panggabean, 2001)

dengan $\quad M_{1}$ adalah rata-rata skor gain kelompok eksperimen, $M_{2}$ adalah rata-rata skor gain kelompok kontrol, $\mathrm{N}_{1}$ sama dengan $\mathrm{N}_{2}$ adalah jumlah siswa, $\mathrm{s}^{2}{ }_{1}$ adalah varians skor kelompok eksperimen, dan $\mathrm{s}^{2}{ }_{2}$ adalah varians skor kelompok kontrol. Hipotesis yang diajukan diterima jika $t_{\text {hitung }}$ $>t_{\text {tabel. }}$

Uji statistik non-parametrik yang akan digunakan jika asumsi parametrik tidak terpenuhi adalah uji Mann-Whitney $U$. Pengambilan keputusannya yaitu apabila nilai dari sig $<1 / 2 \alpha$, dengan $\alpha=0,05$, maka $\mathrm{H}_{\mathrm{i}}$ diterima

\section{HASIL DAN PEMBAHASAN \\ HASIL}

Pemahaman konsep mahasiswa dapat dilihat dari data hasil tes yang dilakukan sebelum dan sesudah pembelajaran dilaksanakan. Ringkasan data statistik hasil penelitian dari tes yang dilaksanakan sebelum dan sesudah pembelajaran dapat dilihat pada table di bawah ini
Tabel 1

\section{Perbandingan Peningkatan pemahaman konsep mahasiswa Kelas Kontrol dan Kelas Ekserimen}

\begin{tabular}{|l|l|l|l|l|}
\hline \multirow{2}{*}{ Kelas } & \multicolumn{2}{|l|}{ Rata- Rata } & $\begin{array}{l}\text { Standar } \\
\text { Deviasi }\end{array}$ \\
\cline { 2 - 4 } & $\begin{array}{l}\text { Prete } \\
\text { st }\end{array}$ & $\begin{array}{l}\text { Post } \\
\text { ets }\end{array}$ & n-gain & \\
\hline Kontrol & 56,4 & 76.6 & 0.46 & 12.0 \\
\hline $\begin{array}{l}\text { Eksperime } \\
\mathrm{n}\end{array}$ & 54.8 & 85.2 & 0.67 & 11.6 \\
\hline
\end{tabular}

Dari tabel 1 dapat diketahui dengan. Perbandingan nilai rata-rata Pre-Test peningkatan pemahaman mahasiswa antara kelas kontrol dengan kelas eksperimen adalah 56,4: 54.8, jadi dari nilai pre test yang angka nya tidak jauh berbeda maka dapat di katakana bahwa kemampuan awal mahasiswa sama.Perbandingan nilai PostTest antara kelas kontrol dengan kelas eksperimen adalah 76.6 : 85.2 di lihat dari nilai post test maka terlihat bahwa nilai post test kelas eksperiment yang menggunakan multimedia interaktif berbasis smartphone lebih tinggi di banding dengan kelas kontrol. Sedangkan, perbandingan Gain ternormalisasi antara kelas kontrol dengan kelas eksperimen adalah 0.46: 0.67 di lihat dari nilai post test maka terlihat bahwa nilai post test kelas eksperiment yang menggunakan multimedia interaktif berbasis smartphone lebih tinggi di banding dengan kelas kontrol.

Berdasarkan perhitungan uji normalitas, diperoleh data bahwa kelas yang menggunakan multimedia interaktif berbasis smartphone maupun kelas yang menggunakan model konvensional dalam proses pembelajarannya diperoleh bahwa $\chi^{2}$ Hitung $<\chi^{2} \quad 0,95$. Sehingga dapat disimpulkan bahwa penyebaran skor pretest kelas eksperimen dan kelas control "berdistribusi normal". 
Berdasarkan perhitungan uji homogenitas diperoleh hasil bahwa Fhitung $\square$ Fdaftar pada taraf kepercayaan $0,95 \%$ yaitu 1,66. Sehingga karena Fhitung $\square$ Fdaftar0,05maka data pre-test kelas yang menggunakan multimedia interaktif berbasis smartphone maupun kelas yang menggunakan model konvensional dalam proses pembelajarannya "homogen".

Setelah dilakukan uji normalitas dan uji homogenitas data dari hasil pretest diketahui bahwa penyebaran skor pretest berdistribusi normal dan homogen sehingga untuk menguji hipotesis digunakan statistik uji parametrik, yaitu dengan uji t dengan taraf signifikansi $\alpha=0,05$.

Berdasarkan hasil dari perhitungan ujit jelas bahwa tidak terdapat perbedaan yang signifikan antara pemahaman mahasiswa kelas eksperimen dan kelas kontrol. Hal itu berarti keadaan awal mahasiswa kelas eksperimen dan kontrol mempunyai kemampuan pemahaman konsep yang sama.

Soal post test diberikan di akhir rangkaian pembelajaran, untuk mengetahui pemahaman konsep mahasiswa setelah mengikuti proses pembelajaran dengan perlakuan menggunakan multimedia interaktif berbasis smartphone maupun pembelajaran konvensional. Berdasarkan hasil perhitungan uji normalitas, kelas yang menggunakan multimedia interaktif berbasis smartphone maupun kelas yang menggunakan model konvensional dalam proses pembelajarannya, diperoleh bahwa $\chi^{2}$ Hitung $<\chi_{2} 2,95$. Sehingga diputuskan bahwa kedua sampel "berdistribusi normal".

Dari tabel hasil uji homogenitas diperoleh hasil bahwa Fhitung $\square$ Fdaftar pada taraf kepercayaan $0,95 \%$ yaitu 1,57 . Sehingga karena Fhitung $\square$ Fdaftar0,05 maka data post-test kelas yang menggunakan multimedia interaktif berbasis smartphone maupun kelas yang menggunakan model konvensional dalam proses pembelajarannya variansinya "homogen".

Setelah dilakukan uji normalitas dan uji homogenitas data dari hasil post test diketahui bahwa penyebaran skor post test berdistribusi normal dan homogeny sehingga untuk menguji hipotesis digunakan statistik uji parametrik, yaitu dengan uji t dengan taraf signifikansi 0,05.

Berdasarkan hasil dari perhitungan uji$\mathrm{t}$, thitung $>$ ttabel dapat disimpulkan bahwa terdapat perbedaan kemampuan akhir pada kelas eksperimen dan kelas kontrol. Dapat disimpulkan bahwa terdapat perbedaan yang signifikan antara kelas yang menggunakan multimedia interaktif berbasis smartphone dibandingkan kelas yang menggunakan model konvensional dalam proses pembelajarannya. Dengan demikian hipotesis diterima yaitu terdapat perbedaan pemahaman konsep antara mahasiswa yang menggunakan multimedia interaktif berbasis smartphone maupun kelas yang menggunakan model konvensional dalam proses pembelajarannya.

\section{PEMBAHASAN}

Berdasarkan hasil analisis data pretes pemahaman konsep mahasiswa, diketahui bahwa skor rata-rata kelas kontrol cenderung sama dengan kelas eksperimen sebelum penerapan multimedia interaktif berbasis smartphone. Dengan demikian dapat disimpulkan bahwa kedua kelas memiliki kemampuan awal yang sama.

Kedua kelompok kelas diberi perlakuan pembelajaran yang berbeda yaitu kelas kontrol menggunakan model pembelajaran konvensional sedangkan kelas eksperimen menggunakan multimedia interaktif berbasis smartphone. Untuk mengetahui peningkatan pemahaman konsep mahasiswa maka dilakukan posttest dan hasilnya dianalisis.

Berdasarkan hasil analisis data, 
mahasiswa yang mendapatkan pembelajaran dengan multimedia interaktif berbasis smartphone secara keseluruhan menunjukkan pemahaman konsep lebih baik dibandingkan dengan mahasiswa yang mendapatkan pembelajaran model konvensional. Tingginya perolehan skor posttest dan gain yang dinormalisasi kelas eksperimen disebabkan karena multimedia interaktif berbasis smartphone mengarahkan mahasiswa pada berbagai aktifitas.selain itu multimedia interaktif dapat lebih meningkatkan motivasi belajar mahasiswa.

Berdasarkan hasil analisis data diperoleh bahwa nilai rata-rata gain yang dinormalisasi untuk kelas eksperimen ialah 0,67 dengan kategori sedang dan nilai ratarata gain yang dinormalisasi untuk kelas kontrol ialah 0,46 dengan kategori sedang. Perbandingan nilai ini secara langsung menunjukkan bahwa penggunaan multimedia interaktif berbasis smartphone dapat lebih efektif meningkatkan pemahaman konsep siswa dibandingkan dengan pembelajaran konvensional berbantuan multimedia.

Dahar (1989) menyatakan bila seorang anak selama belajar sains hanya diberi informasi tentang sains yang sudah ada dengan cara mendengarkan penjelasan guru, maka sains itu sendiri akan berhenti berkembang. Sains bukan hanya pengetahuan yang terdiri dari fakta-fakta, prinsip-prinsip, konsep-konsep dan teoriteori yang dikenal dengan produk sains, melainkan juga keterampilan-keterampilan dan sikap-sikap yang diperlukan untuk mencapai produk sains yang dikenal dengan proses sains

\section{KESIMPULAN}

Berdasarkan data dan analisis hasil penelitian yang telah dilakukan tentang penerapan pembelajaran multimedia interaktif berbasis smartphone pada mata kuliah fisika dasar untuk mengembangkan pemahaman konsep mahasiswa dapat disimpulkan bahwa: multimedia interaktif berbasis smartpohe secara signifikan dapat lebih meningkatkan pemahaman konsep mahasiswa dibandingkan dengan model pembelajaran konvensional

\section{DAFTAR PUSTAKA}

Ahmed, S., \& Parsons, D. (2013). Abductive science inquiry using mobile devices in the classroom. Computers and Education, 63, 62-72. https://doi.org/10.1016/j.compedu.201 2.11 .017

Dahar, R Wilis. (1989). Teori-teori Belajar. Jakarta: Erlangga.

France, D., Powell, V., Mauchline, A. L., Welsh, K., Park, J., Whalley, W. B., \& Rewhorn, S. (2016). Ability of students to recognize the relationship between using mobile apps for learning during fieldwork and the development of graduate attributes. Journal of Geography in Higher Education, 8265(March), 1-11. https://doi.org/10.1080/03098265.201 6.1154931

Gikas, J., \& Grant, M. M. (2013). Mobile computing devices in higher education: Student perspectives on learning with cellphones, smartphones \& social media. Internet and Higher Education, 19 , 18-26. https://doi.org/10.1016/j.iheduc.2013. 06.002

Hopkins, N., Tate, M., Sylvester, A., \& Johnstone, D. (2016). Motivations for 21 st century school children to bring their own device to school. Information Systems Frontiers, (Douglas 2011), 113. https://doi.org/10.1007/s10796016-9644-z

Ismail, A. (2011). Penerapan model Pembelajaran Children Learning In Science (CLIS) Berbantuan 
Multimedia Untuk Meningkatkan Keterampilan Proses Sains Dan Penguasaan Konsep Siswa pada Pokok Bahasan Fluida (Doctoral dissertation, Universitas pendidikan indonesia).

Ismail, A. (2015). Penerapan Model Pembelajaran Children Learning In Science (CLIS) Berbantuan Multimedia Untuk Meningkatkan Penguasaan Konsep Fisika Siswa SMA. Jurnal PETIK, 1 (1), 26-37.

Ismail, A. (2017). Penerapan Model Pembelajaran Children Learning In Science (CLIS) Berbantuan Multimedia Untuk Meningkatkan Keterampilan Proses Sains Siswa Sma Pada Pokok Bahasan Fluida. JIPFRI (Jurnal Inovasi Pendidikan Fisika Dan Riset Ilmiah), 1(2), 83-87.

Li, Y., Guo, A., Ling Chin, C., \& Lim, J.-H. (2016). A platform for creating Smartphone apps to enhance Chinese learning using augmented reality. Scientific Phone Apps and Mobile Devices.

https://doi.org/10.1186/s41070-0160007-4

Nasrulloh, I., \& Ismail, A. (2017). ANALISIS KEBUTUHAN PEMBELAJARAN BERBASIS ICT. Jurnal PETIK, 3(1), 28-32.

Noguera, J. M., Jiménez, J. J., \& OsunaPérez, M. C. (2013). Development and evaluation of a 3D mobile application for learning manual therapy in the physiotherapy laboratory. Computers
\& Education, 69, 96-108. https://doi.org/10.1016/j.compedu.201 3.07.007

Panggabean, Luhut P. (2001). Statistika Dasar. Bandung: Jurusan Pendidikan Fisika FPMIPA UPI.

Selahattin, G. Kocakaya. dan Inan (2006). "the effect of the computer assisted teaching and $7 \mathrm{e}$ model of the constructivist learning methods on the achievements and attitudes of high school students". The Turkish Online Journal of Educational Technology.

Shih, B.-Y., Chen, C.-Y., \& Chen, Z.-S. (2006). An Empirical Study of an Internet Marketing Strategy for Search Engine Optimization. Human Factors and Ergonomics in Manufacturing, 16(1), 61-81. https://doi.org/10.1002/hfm

Thomas, R. L., \& Fellowes, M. D. E. (2016). Effectiveness of mobile apps in teaching field-based identification skills. Journal of Biological Education, 9266(July), $1-8$. https://doi.org/10.1080/00219266.201 6.1177573

Vázquez-Cano, E. (2014). Mobile Distance Learning with Smartphones and Apps in Higher Education. Educational Sciences: Theory \& Practice, 14(4), 1505-1520.

https://doi.org/10.12738/estp.2014.4.2 $\underline{012}$ 